\title{
HUBUNGAN PERGAULAN DAN PERKEMBANGAN MORAL TERHADAP AKTIVITAS BELAJAR SISWA
}

\author{
Nur Sakinah ${ }^{1}$ \\ ${ }^{1}$ Universitas Muhammadiyah Sumatera Utara, Medan
}

Sakinahn077@gmail.com

\begin{abstract}
Abstrak
Salah satu indikator menurunnya aktivitas belajar siswa adalah pergaulan siswa. Di samping itu juga, ada kecenderungan perkembangan moral siswa yang kurang baik. Kedua indikator tersebut memiliki hubungan yang signifikan terhadap kecenderungan aktivitas belajar siswa. Oleh karena itu, perbaikan dan peningkatan pada pergaulan dan perkembangan moral akan membawa dampak positif bagi peningkatan aktivitas belajar siswa.Penelitian ini bertujuan untuk melihat dan menelaah sampai sejauh mana hubungan pergaulan dan perkembangan moral terhadap aktivitas belajar siswa di Madrasah Aliyah Muhammadiyah Mandala Medan.
\end{abstract}

\section{Kata Kunci: Pergaulan dan Perkembangan Moral}

\section{Pendahuluan}

Pembangunan nasional pada hakikatnya merupakan pembangunan manusia Indonesia seutuhnya. Untuk mewujudkan hal tersebut, pemerintah berupaya mempersiapkan generasi muda yang berkualitas dengan konsep dasar pertumbuhan dan perkembangan anak secara keaktifan dan holistic, yang mencakup aspek pelayanan pendidikan, kesehatan dan gizi yang diarahkan pada upaya terwujudnya perbaikan atau kemajuan dalam kelangsungan hidup anak. Fase dini merupakan fase emas (golden age) bagi pengembangan anak, karena pada fase ini sangat menetukan bagi pengembangan anak hingga ia memasuki usia dewasa.

Aspek perkembangan anak yang harus dikembangkan menurut Jalal ${ }^{1}$ mencakup aspek perkembangan moral dan nilai agama, aspek fisik, aspek bahasa, aspek kognitif dan aspek sosial emosional serta seni. Pertumbuhan dan perkembangan moral serta pergaulan sudah dapat diantisipasi sejak anak-anak memasuki jenjang pendidikan menengah. Akan tetapi, jika anak-anak sudah sampai pada tarap pubertas atau remaja, pendidikan dan pengontrolan pergaulannya sudah harus semakin ditingkatkan, karena pada masa ini anak anak sangat rentan terhadap segala macam pergaulan yang tidak sesuai dengan nilai-nilai agama dan moral masyarakat.

Setiap pendidikan harus menyadari bahwa setiap fase perkembangan akan membawa perubahan baru pada anak, baik secara jasmani maupun rohani. Ada beberapa hal yang perlu diketahui orang tua sesuai dengan perkembangan anak, yaitu:

1. Setiap fase yang dialami oleh anak adalah masa peralihan atau masa persiapan bagi masa selanjutnya.

2. Perkembangan yang dialami oleh anak adalah perkembangan jasmani dan rohani. Oleh karena itu, dalam usaha membantu perkembangan anak, orang tua dan guru diharapkan agar memperhatikan perkembangan ini dan senantiasa melakukan kontrol dan pertimbangan agar tidak terjadi kelalaian pada diri anak.

${ }^{1}$ Fasli Jalal, Stimulasi Otak untuk Mengoptimalisasi Kecerdasan Anak, Buletin PAUD, Jurnal Ilmiah Anak Usia Dini, Cetakan Pertama, Edisi 02 (Jakarta: Direktorat PADU, 2002), h. 12. 
3. Dalam keluargalah anak itu berkembang, oleh karena itu keluarga menduduki tempat penting bagi terbentuknya pribadi anak secara keseluruhan yang akan dibawa sepanjang hidupnya. Keluargalah pembentuk watak, pemberi rasa dasar keagamaan, penanam sifat, kebiasaan, hobi, cita-cita dan sebagainya, serta lembaga-lembaga lain di masyarakat adalah sekedar membantu, melanjutkan, memperbanyak dan memperdalam apa yang diperoleh dari keluarga. ${ }^{2}$

Keluarga merupakan lingkungan yang pertama memberikan pendidikan yang berpengaruh terhadap perkembangan anak didik. Dalam keluarga anak akan mendapat kesempatan yang baik untuk memperoleh nilai-nilai moral keagamaan yang diterimanya dari orang tua. Fungsi kepemimpinan dan keteladanan orang tua dapat membentuk kepribadian anak, sedangkan pergaulannya di masyarakat secara fungsional dapat berdampak positif dan negatif terhadap perkembangan moral anak.

Disamping itu, dalam keluargalah anak mula-mula mengenal nilai-nilai kebaikan melalui ucapan-ucapan dan bacaan-bacaan, juga berbagai contoh dan teladan yang bakal dipraktikannya terhadap kehidupan sosial, bagaimana harus bersikap pada orang tua dan orang lain. Kasih sayang yang diberikan orang tua akan membawa pengaruh yang besar dalam perkembangan jiwa anak. Anak yang kehilangan kasih sayang akan mempengaruhi hidupnya di masa yang akan datang.

Lingkungan di mana anak akan hidup dan bergaul mempunyai peranan yang sangat besar dalam membentuk jiwa kepribadian anak. Lingkungan yang baik akan mendorong anak untuk melakukan kegiatan dalam mengembangkan segala bakat dan potensi yang dimilikinya. Lingkungan yang tidak bagus akan mempengaruhi perkembangannya sehingga bakat dan potensi yang baik yang dimilikinya akan mengalami hambatan dalam perkembangannya.

Pendidikan yang diperoleh di sekolah diarahkan untuk mencapai kedewasaan. Ciri kedewasaan dapat dijabarkan dalam pengetahuan, pemahaman, keterampilan, sikap dan nilai yang harus dimiliki siswa setelah ia menyelesaikan pendidikannya. ${ }^{3}$

Namun, akibat salah bimbingan dan salah pergaulan, dapat mengganggu tujuan pendidikan, baik ketika di rumah maupun di madrasah. Malah pada saat sekarang ini, sudah sering dijumpai dalam media massa tentang kejadian-kejadian anak yang menganiaya orang tua dan juga gurunya. Kejadian ini merupakan salah satu dari pengaruh perkembangan zaman yang telah mengubah tata nilai di antara para siswa.

Berkurangnya penghargaan dari guru dan menipisnya kebutuhan terhadap nilai-nilai agama akan menjauhkan anak dari nilai-nilai moral yang seharusnya dimiliki. Guru tidak pernah meminta untuk dihargai, tetapi memang sudah menjadi kewajiban bagi siswa untuk menghormati dan menghargainya karena jasa dan dedikasinya dalam mendidik siswa. Karena jasa dan pengorbanannya tercipta generasi yang cerdas, cakap, dan dengan jasanya pula akan tercipta orang yang intelek, berhasil dan maju.

Berkurangnya nilai moral dan etika di kalangan para siswa banyak yang menjadi faktor penyebabnya. Apa yang diperoleh di madrasah tidak dapat disesuaikan dengan apa yang dijumpainya di masyarakat, sehingga ia bingung arah aman yang harus ia lalui. Disamping itu juga karena kurangnya perhatian orang tua terhadap anak, sehingga apapun yang dilakukan anak di luar rumah, orang tua tidak tahu akibat dari kesibukkannya.

Besarnya pengaruh pergaulan ini dapat mempengaruhi juga perkembangan jiwa siswa. Jika siswa mampu mengendalikan pergaulannya dan menilai yang positif untuk diteladani, maka perkembangan moral siswa akan terhindar dari kebobrokan moral, namun jika siswa mengarah kepada perkembangan yang negatif, maka moral siswa akan mengarah

${ }^{2}$ Agus Suyanto, Psikologi Perkembangan, Cetakan Kelima (Jakarta: Aksara Baru, 1999), h. 72.

${ }^{3}$ W.S Winkel, Psikologi Pengajaran,Cetakan Kedua (Jakarta: Gramedia Widya Sarana Indonesia, 1989), h. 21. 
pula yang negatif. Pergaulan-pergaulan ini besar pengaruhnya terhadap aktivitas belajar siswa.

Jika dilihat dari aktivitas belajar siswa, pergaulan merupakan salah satu faktor yang dapat mempengaruhi belajar siswa. Pengaruh-pengaruh dari teman bergaul siswa lebih cepat masuk dalam jiwanya dari pada yang di duga. Teman bergaul yang baik akan berpengaruh baik terhadap diri siswa, begitu juga sebaliknya teman bergaul yang buruk juga pasti mempengaruhi sifat yang buruk pula. Agar siswa dapat belajar dengan baik, maka perlu diusahakan agar siswa memiliki teman bergaul yang baik dan pembinaan pergaulan serta pengawasan dari orang tua dalam pendidikan harus cukup bijaksana. ${ }^{4}$

\section{Kajian teoritis}

Dalam proses belajar mengajar siswa merupakan sasaran pemberian bantuan oleh guru. Sebab tujuan dan interaksi edukatif adalah membimbing dan membantu siswa dalam perubahan tingkah laku. Perubahan yang terjadi ketika berlangsungnya pelajaran, seringkali menimbulkan suatu perubahan karena cita-cita kehidupan. Disamping itu, proses belajar juga dapat memperkuat arah cita-cita siswa. Proses itu dapat dengan cepat membantu siswa untuk maju kearah tujuan yang diharapkan. Oleh karena itu, para siswa harus memiliki sikap yang baik serta mental yang tangguh, bersungguh-sungguh dalam belajar, sehingga kalau hal ini disadari oleh para siswa, maka siswa akan memiliki tanggung jawab terhadap diri sendiri dan berusaha mencari ilmu seoptimal mungkin.

Aktifitas belajar siswa, baik di kelas maupun di luar kelas pada prinsipnya adalah sarana pengembangan diri, aktifitas belajar dapat dimulai dengan cara belajar memahami dan menghafal berbagai macam pelajaran, sebagaimana dijelaskan oleh al-Abrasyi, ${ }^{5}$ bahwa menuntut ilmu yang pertama adalah niat, kemudian mendengarkannya, kemudian memahaminya, setelah itu menghafalnya, kemudian mengamalkannya dan setelah itu menyebarluaskannya. Artinya, bahwa manusia pertama berniat hendak belajar kemudian mendengarkannya dan penuh perhatian dengan apa yang diuraikan tersebut, selanjutnya menghapalkannya dan menyebarluaskan pendapat dan buah pikiran di antara manusia.

Sejalan dengan pandangan di atas, dalam proses belajar mengajar siswa diberikan kebebasan berbuat dan bertindak atas dasar kreativitas sendiri, belajar sambil berbuat adalah menjadi tujuan dalam proses pendidikan. Tetapi, jika siswa itu sendiri tidak konsentrasi terhadap pelajarannya dan bermalas-malasan serta menganggap sepele, maka proses belajar mengajar tidak akan berjalan dengan lancer, juga apabila siswa tidak memiliki moral yang bagus akan mempengaruhi proses belajar mengajar. Belajar dikatakan produktif apabila siswa dapat menggunakan pengetahuannya mendapatkan gagasan yang baru, memecahkan permasalahan, menyusun rencana kegiatan, dan mengadakan eksperimen. ${ }^{6}$

Menyampaikan bahan pelajaran berarti melaksanakan beberapa kegiatan, tetapi kegiatan itu tidak akan ada gunanya jika tidak mengarah pada tujuan tertentu. Artinya seorang guru harus mempunyai tujuan dalam kegiatan pengajarannya, karena itu setiap guru menginginkan setiap pengajarannya dapat diterima sejelas-jelasnya oleh peserta didiknya. Untuk mengerti suatu hal dalam diri seseorang, terjadi suatu proses yang disebut sebagai proses belajar melalui model-model mengajar yang sesuai dengan kebutuhan proses belajar itu. Melalui model-model mengajar, guru mempunyai tugas merangsang serta meningkatkan jalannya proses belajar. Untuk dapat melaksanakan tugas itu dengan baik, guru harus

\footnotetext{
${ }^{4}$ Slameto, Belajar dan Faktor-Faktor yang Mempengaruhinya, Cetakan Ketiga (Jakarta: PT. Rineka Cipta, 1991), h. 71.

${ }^{5}$ M. Athiyah al-Abrasyi, Dasar-Dasar Pendidikan Islam, Cetakan Pertama (Jakarta:Bumi Aksara, 1970), h. 135-136.

${ }^{6}$ Ibid., h. 136.
} 
mempunyai kemampuan dan mengetahui bagaimana model serta proses pembelajaran itu berlangsung.

Model dan proses pembelajaran akan menjelaskan makna kegiatan-kegiatan yang dilakukan oleh pendidik selama pembelajaran berlangsung. Setiap pengajar atau pendidik akan alasan-alasan mengapa ia melakukan kegiatan dalam pembelajaran dengan menentukan sikap tertentu. Mengemukakan bahwasanya bilaman pengajar tidak mengetahui apa yang sebenarnya yang terjadi dalam pikiran peserta didiknya untuk mengerti sesuatu, kiranya dia pun tidak akan dapat memberi dorongan yang tepat kepada mereka yang sedang belajar. Para peserta didik akan mudah melupakan pelajaran yang diterimanya, jika pengajar tidak memberi penjelasan yang benar dan menyenangkan.

Kemampuan guru dalam mengelola pembelajaran salah satunya adalah penciptaan proses belajar belajar yang kondusif, juga proses pengolahan informasi. Proses tersebut terjadi melalui mental proses yang secara individual diarahkan untuk mencapai tujuan yang diharapkan. Jika belajar bersifat individual, maka hasil belajar juga bersifat individual. Artinya, sekalipun dalam sebuah pengajaran seorang guru memberikan informasi yang sama kepada peserta didik, setiap peserta didik akan memperolah hasil yang berbeda.

Perbedaan hasil tersebut, tergantung sepenuhnya kepada bagaimana peserta didik yang bersangkutan mengolah atau memproses informasi tersebut secara umum meliputi proses mengumpulkan dan menyeleksi informasi melalui pancaindera, menyusun atau menata informasi yang telah diseleksi ke dalam memori dan menggunakan informasi yang tersimpan dalam memori untuk melakukan sesuatu perbuatan. ${ }^{8}$

Masalah moral merupakan masalah yang menjadi pemikiran bagi masyarakat, baik masyarakat yang maju maupun masyarakat terbelakang. Sebab kerusakan moral dapat mengganggu ketenteraman orang lain. Jika dalam suatu masyarakat, warganya banyak yang telah rusak moralnya maka akan goncanglah keadaan masyarakat tersebut. Dengan demikian, apa yang dimaksud dengan moral dalam hal akan diuraikan beberapa pengertiannya.

Menurut Elizabeth Hurlock, ${ }^{9}$ bawa moral secara benar adalah tingkah laku yang sesuai dengan ukuran sosial yang juga dilaksanakan secara suka rela oleh individu/manusianya. Moral tersebut ada bersamaan dengan perubahan kekuasaan dari yang eksternal kepada yang internal terdiri dari tindakan/perilaku yang diatur dalam individu tersebut. Moral tersebut juga diiringi oleh suatu perasaan terhadap pertanggungjawaban dengan tindakannya tersebut. Sedangkan kehendak pribadi atau apa-apa yang diperolehnya diturunkan ataupun diasingkan untuk tambahan dari kepentingan kedua. Pengertian perkembangan hubungan sosial manusia tumbuh dan berkembang pada masa bayi ke masa dewasa melalui beberapa langkah dan jenjang.

Sesuatu hal yang terpenting adalah moralitas yang sungguh-sungguh. Moralitas adalah ajaran, tata, baik perbuatan dan kelakuan (akhlak). Selain kata moral Islam juga mengenal kata lain yaitu akhlak, etika. Kedua kata tersebut mengacu kepada tujuan yang sama yaitu budi pekerti. Etika, akhlak maupun moral mempunyai arti yang sama yaitu kebiasaan yang menjelaskan baik dan buruknya perbuatan yang dilakukan manusia. Bedanya adalah yang menetapkan etika adalah manusia sedangkan akhlak merupakan ketetapan dari Tuhan.

7 AndulMu'ti, Proses Belajar: Pendekatan Kognitif, dalam PBM-PAI di Sekolah: Eksistensi dan Proses Belajar Mengajar Pendidikan Agama Islam, Semarang: Fakultas Tarbiyah IAIN Wali Songo Semarang, 1998, hlm. 96.

${ }^{8}$ Ulrich Neisser, Cognition nd Reality, Cetakan Pertama, San Fransisco: W.H. Freeman, 1976, hlm.1.

9 Elizabeth Hurlock, Psikologi Perkembangan: Suatu Pendidikan Sepanjang Rentang Kehidupan, Cetakan Ketiga, terj. Istiwidayanti, (Jakarta: Erlambang, 1991), h. 81. 
Jika ditinjau dari ajaran agama Islam itu sendiri, maka yang terpenting adalah tentang akhlak. Hal ini dapat dilihat dari perkataan Nabi yang menunjukkan bahwa, Dia (Ahmad) diutus Tuhan untuk menyempurnakan akhlak manusia.

Dari uraian tersebut dapat dijelaskan bahwa dilihat dari sumber dan sifatnya moral terbagi kepada dua bagian, yaitu:

1 Moral keagamaan, yang bersumber dari ajaran-ajaran agama.

2 Moral sekuler yaitu moral yang bersumber dari ajaran agama, melainkan dari norma yang ada di masyarakat. ${ }^{10}$

Moral keagamaan dan moral sekuler sekalipun sama yaitu baik dan buruk yang dilakukan manusia. Tetapi penilaian terhadap keduanya sangat berbeda, sebab pada moral keagamaan baik buruknya perbuatan manusia dinilai berdasarkan ajaran agama yang telah ada, seperti seseorang yang dianggap baik menurut ajaran agama Islam jika ia melaksanakan ajaran agama.

Moral sekuler merupakan ukuran baik dan buruk yang dilakukan manusia berdasarkan penilaian masyarakat. Ukuran masyarakat sudah baik belum tentu ajaran agama juga mengatakan baik, seperti contoh; masyarakat menilai bukanlah suatu hal yang buruk jika ada pemilihan ratu kecantikan yang sering diadakan dan dijadikan ajang penilaian kecantikan seseorang. Hal ini jika ditinjau dari segi agama sudah dianggap buruk.

Karakter disebut juga kepribadian, sebagaimana dijelaskan oleh James Draver, yaitu: Personality a term used in various sens, both popularly and psychologically. The most comprehensive and satisfactory being the integrated and dynamic organization of the physical, mental, moral, and social qualities of the individual, as the manifest it self to other people, in the give and take of social life. ${ }^{11}$ (kepribadian adalah termasuk yang digunakan dalam banyak arti baik pengertian yang populer maupun dalam pengertian psikologi, yang paling mencakup dan memuaskan adalah (yang mengartikan sebagai) suatu organisasi (himpunan) yang terpadu dan dinamis antara fisik, mental, moral dan nilai-nilai sosial dari seseorang sebagai manifestasi dirinya terhadap orang lain secara timbal balik di dalam kehidupan masyarakat).

Kepribadian meliputi kualitas keseluruhan dari seorang. Kualitas itu akan tampak dalamm cara-cara berbuat, cara-cara berpikir, cara-caranya mengeluarkan pendapat, sikapnya, minatnya, filsafat hidupnya serta kepercayaannya. ${ }^{12}$

Berdasarkan kutipan di atas, maka dapat disimpulkan bahwa karakteristik siswa dapat dirubah dengan pendidikan yang intensif dan terencana, baik dalam perencanaan pembelajaran maupun silabus. Dalam proses belajar mengajar, seorang pendidik harus sedapat mungkin mamahami hakikat peserta didiknya sebagai subjek dan objek pendidikan. Beberapa hal yang perlu dipahami mengenai karakteristik peserta didik menurut Suwarno, ${ }^{13}$ adalah:

Pertama, peserta didik bukan miniatur orang dewasa, ia mempunyai dunia sendiri, sehingga metode belajar mengajar tidak boleh di samakan dengan orang dewasa. Orang dewasa tidak patut mengeksploitasi dunia peserta didik, dengan mematuhi segala aturan dan keinginannya, sehingga peserta didik kehilangan dunianya. Peserta didik yang kehilangan dunianya, maka menjadikan kehampaan hidup di kemudian hari.

Kedua, peserta didik memiliki kebutuhan dan menuntut untuk pemenuhan kebutuhan itu semaksimal mungkin. Kebutuhan individu, menurut Abraham Maslow,

\footnotetext{
${ }^{10}$ Tatapangarsa Humadi, Akhlak yang Mulia, Cetakan Ketiga, (Surabaya: Bina Ilmu, 1991), h. 9.

${ }^{11}$ James Draver, The Pinguin Dictionary of Psychology, Cetakan Kedua, (Aucland New Zeland: Penguin Book, 1981), hlm. 208.

12 Ahmad D. Marimba, Pengantar Filsafat Pendidikan Islam, Cetakan Keempat, (Bandung: al-Ma'arif, 1986), hlm.67.

${ }^{13}$ Suwarno, Pengantar Ilmu Pendidikan, Cetakan Ketiga, (Jakarta: Aksara Baru, 1982), hlm. 85.
} 
'Terdapat lima hierarki kebutuhan yang dikelompokkan dalam dua kategori, yaitu: (1) kebutuhan tariff dasar (basic needs) yang meliputi kebutuhan fisik, rasa aman dan terjamin, cinta dan ikut memiliki (sosial), dan harga diri, (2) meta kebutuhan-meta kebutuhan (meta needs), meliputi apa saja yang terkandung dalam aktualisasi diri, seperti keadilan, kebaikan, keindahan, keteraturan, kesatuan dan lain sebagainya." 14

Ketiga, peserta didik memiliki perbedaan antara individu dengan individu yang lain, baik perbedaan yang disebabkan dari faktor endogen (fitrah), maupun eksogen (lingkungan) yang meliputi segi jasmani, inteligensi, sosial, bakat, minat, dan lingkungan yang mempengaruhinya. Dalam teori psikologi, ${ }^{15}$ terdapat tiga bagian tentang individu:

1) Seperti semua orang lain, yang karenanya perlu perlakuan pendidikan yang sama satu dengan yang lain;

2) Seperti sejumlah orang lain, yang karenanya perlu perlakukan pendidikan yang berbeda antara anak yang umum (kecerdasannya rata-rata) dengan yang khusus (sangat cerdas/bodoh);

3) Seperti tidak semua orang lain pun, yang karenanya perlu perlakuan pendidikan yang berbeda antara individu satu dengan yang lain.

Keempat, peserta didik dipandang sebagai satu kesatuan sistem manusia. Sesuai dengan hakikat manusia, seperti didik sebagai makhluk monopluralis, maka pribadi peserta didik walaupun terdiri dari banyak segi, merupakan satu kesatuan jiwa raga (cipta, rasa, dan karsa).

Kelima, peserta didik merupakan subjek dan objek sekaligus dalam pendidikan yang dimungkinkan dapat aktif, kreatif, serta produktif. Setiap peserta didik memiliki aktifvitas sendiri (swadaya) dan kreativitas sendiri (daya cipta), sehingga dalam pendidikan tidak memandang anak sebagai objek pasif yang biasanya hanya menerima, mendengar saja.

Keenam, peserta didik mengikuti periode-periode perkembangan tertentu dan mempunyai pola perkembangan serta tempo dan iramanya. Implikasi dalam pendidikan adalah bagaimana proses pendidikan itu dapat disesuaikan dengan pola dan tempo, serta irama perkembangan pserta didik. Kadar kemampuan peserta didik sangat ditentukan oleh usia atau periode perkembangannya, karena usia itu bisa menentukan tingkat pengetahuan, intelektual, emosi, bakat, minat peserta didik, baik dilihat dari dimensi biologis, psikologis maupun didaktis.

Pembentukan karakter siswa dalam kegiatan belajar mengajar memerlukan persiapan dan kesabaran serta tindak lanjut yang kontinu, karena karakter peserta didik memiliki karakteristik tersendiri. Setiap individu memiliki perbedaan, sedangkan pada sisi pendidikan mereka peserta didik harus mengarah kepada perubahan yang pasti, di sinilah diperlukan pendekatan yang lebih komprehensif. Oleh karena itu, pendidikan harus mengetahui faktorfaktor apa saja yang dapat mempengaruhi pembentukan karakter siswa, di antara faktorfaktor tersebut adalah:
a. Faktor fisik
b. Faktor akal
c. Faktor keberagamaan
d. Faktor akhlak
e. Faktor Rohani (kejiwaan)
f. Faktor seni (keindahan)

\footnotetext{
${ }^{14}$ Abraham H. Maslow, Motivation and Personality, (New York: Harper and Row Publishing,, 1970), hlm. 3747.

15 A. Supraktiknya, dalam kata Pengantar, Hall, Calvin, and Gardner Lindsey, Teori-Teori Psikodinamik (klinis), terj. Yustinus, judul asli, Theories of Personality, Cetakan Keempat, (Yogyakarta: Kanisius, 1993), hlm. 3.
} 


\section{g. Faktor Sosial. ${ }^{16}$}

Semua faktor di atas, diyakini dapat menjadi pendorong bagi peserta didik untuk mengembangkan karakternya. Karena manusia atau peserta didik mudah berubah manakala apa yang didengar dan dilihatnya dapat menarik hatinya. Menurut Widodo Supriono, ${ }^{17}$ manusia merupakan makhluk multidimensional yang berbeda dengan makhluk-makhluk lainnya. Secara garis besar ia membagi manusia pada dua dimensi yaitu dimensi fisik dan rohani. Secara rohani, manusia mempunyai potensi kerohaniahan yang tak terhingga banyaknya. Potensi-potensi tersebut tampak dalam bentuk memahami sesuatu (ulil al bab), dapat berpikir/merenung, menggunakan akal, dapat beriman, bertaqwa, mengingat atau mengambil pelajaran, mendegar kebenaran firman Tuhan, dapat berilmu, berkesenian, dapat menguasai teknologi tepat guna dan terakhir manusia lahir ke dunia telah membawa fitrah.

Manusia pada hakikatnya merupakan makhluk sosial.sejak manusia lahir ke dunia selalu membutuhkan orang lain untuk memenuhi kebutuhan hidupnya. Setelah besar juga manusia tidak bisa lepas dari hubungannya dengan orang lain dan masyarakatnya. Dalam menjalin hubungan sosial perlu adanya penyesuaian diri, dan dengan adanya penyesuaian diri yang baik seseorang bisa diterima dalam suatu kelompok dalam rangka mencapai tujuan hidupnya.

Dalam memenuhi kebutuhan hidup manusia, setiap individu secara sosial dibantu orang lain, untuk keperluan tersebut manusia harus berhubungan dalam pergaulannya dengan orang lain, tidak terkecuali anak-anak yang masih belajar pada Sekolah Lanjutan Tingkat Atas (SLTA). Ada beberapa sebab yang mengakibatkan anak harus keluar rumah dan bergaul dengan orang lain seperti: kekurangan fasilitas belajar, menghilangkan kejenuhan dan tuntutan hidup masyarakat. ${ }^{18}$

Fasilitas merupakan salah satu faktor yang mendukung dalam mencapai tujuan dalam proses belajar mengajar. Peserta didik yang kekuranan fasilitas belajar menyebabkan ia mencarinya di luar dan bergaul di luar rumah. Karena fasilitas belajar tidak terpenuhi maka peserta didik berusaha untuk mendapatkannya dari orang lain, maka salah satu cara yaitu dengan meminjamnya dari orang lain dan tidak menuntut pergaulan. ${ }^{19}$

Dalam pergaulan antar manusia, baik di kampung lebih-lebih pada forum internasional yaitu pergaulan antar bangsa selalu diperlukan etika atau lebih tepat etike (tata sopan santun) pergaulan. Nampaknya hal ini merupakan fitrah manusia bahwa manusia memiliki rasa ingin dihargai oleh orang lain dan sekaligus ingin menghargai orang lain. Sehingga ungkapan yang terkenal dalam kehidupan sehari-hari di kalangan kita adalah "jika ingin dihargai oleh orang lain, maka hargailah orang lain" Dari rasa ingin menghargai orang lain inilah, seseorang berupaya bersikap dan berperilaku sopan. Intinya adalah bagaimana kita bersikap dan betingkah laku sopan kepada orang lain.

Dalam pergaulan, orang perlu mengenal tata cara dalam pembicaraan tatap muka serta pembicaraan dengan sarana komunikasi, misalnya telepon dan surat menyurat (tata karma dalam berkomunikasi dengan orang lain sesama remaja harus tetap dijaga. Komunikasi dalam pergaulan adalah kegiatan sehari-hari kita seperti makan, minum. Dalam kenyataan, ternyata tidak semua orang termasuk remaja mampu berkomunikasi secara baik dengan orang lain, apakah kepada orang tuanya, tetangganya, gurunya, bahkan dengan teman sendiri sekali pun. Kemampuan berkomunikasi dengan baik nampaknya memerlukan latihan dan pembiasaan. Ada orang yang ketika berkomunikasi dengan orang lain sering menyinggung perasaan orang lain, ada yang canggung, bahkan senang menyendiri, karena ketidakmampuannya

\footnotetext{
${ }^{16}$ Rayamulis, Ilmu Pendidikan Islam, Cetakan Ketiga, hlm. 120.

${ }^{17}$ Widodo Supriono, Filsafat Manusia dalam Islam , Reformasi Filsafat Pendidikan Islam, Cetakan Kelima, (Pustaka Pelajar, Jogyakarta, 1996), hlm. 179.

${ }^{18}$ W.A Gerungan, Psikologi Sosial, dicetak Oleh Rosda Offset, (Bandung: Erasco, 1991), h. 312.

${ }^{19}$ Ibid., h. 137.
} 
berkomunikasi dengan orang lain. Ada beberapa kunci pokok yang perlu dicamkan guna mengatasi masalah komunikasi ini.

Pertama, perlakukanlah orang lain sebagaimana kita ingin diperlakukan.

Kedua, setiap orang mempunyai perbedaan-perbedaan individual. Jadi, terimalah sifat tertentu teman kita itu, yang mungkin agak aneh dirasakan.

Ketiga, kenal dulu baru sayang, makin kenal makin sayang. Kita pun perlu membuka diri agar bisa dikenal oleh orang lain.

Keempat, tumbuhkan kepercayaan kepada orang lain, cinta kasih kepada orang lain, dan kesediaan berkorban kepada orang lain.

Disamping masalah tata karma dalam berkomunikasi dengan orang lain khsusunya sesama remaja, juga tata karma ketika berkenalan dan bertamu di rumah orang. Waktu kita berkenalan dengan orang lain pada umumnya kita berjabat tangan dengan orang lain. Kalau kita bertamu ke rumah orang, termasuk ke rumah teman sendiri, hendaknya kita datang pada waktu yang tepat, tidak pada waktu sedang istirahat (tidur) siang. Akan lebih baik, jika sebelum kita bertamu, kita berkabar terlebih dahulu apakah lewat telepon rumah atau lewat telepon genggam dengan mengirim SMS.

Kalau Kita bertamu pintu dalam keadaan tertutup rapat, sebaiknya kita mengetuk pintu sampai tiga kali. Kalau sudah diketuk sebanyak tiga kali ternyata pintu tidak juga dibuka, sebaiknya kita pulang, dan jangan memaksa diri. Tatakrama atau adat sopan santun juga diperlukan ketika kita berbicara dengan orang lain, termasuk teman kita sendiri. Waktu kita berbicara hendaklah kita tenang dan sekali-sekali boleh ditegaskan pembicaraan dengan gerak tangan secara halus dan sopan.

Gerak tangan hendaklah tidak berlebihan. Pilihlah pokok pembicaraan yang tidak menyinggung perasaan lawan bicara kita. Hindari pula menggunjingkan orang lain termasuk teman kita sendiri. Biasakanlah mendengarkan orang lain dan jangan memotong pembicaraan lawan bicara kita. Berbisik-bisik dengan teman di tengah orang-orang sebaiknya dihindari, karena dapat mengundang rasa tidak simpatik orang lain yang melihatnya. Ketika berbicara, sebaiknya selalu memperhatikan dengan siapa kita sedang berbicara.

Berbicara dengan orang tua tentu berbeda dengan ketika berbicara dengan teman kita sendiri. Seakrab apa pun kita dengan teman kita, tata karma atau adat sopan santun harus tetap dijaga. Ketika kita bertelepon pun kita harus menggunakan tata karma bertelepon, ketika kita bersurat menyurat dengan teman kita pun harus menggunakan tata krama surat menyurat. Jika hal itu bisa kita lakukan kita pasti banyak teman. Akhir-akhir ini, banyak kita temukan perilaku remaja yang kurang mengindahkan tata sopan santun yang berlaku di masyarakat. Misalnya, sebagian murid di suatu sekolah yang tetap duduk-duduk di atas meja, padahal ada bapak atau ibu guru berjalan di depannya.

Disamping itu, pergaulan juga harus dilandasai dengan pemikiran yang jernih dan juga inteligensi. Inteligensi adalah suatu daya jiwa untuk dapat menyesuaikan diri dengan cepat dan tepat di dalam situasi yang baru. ${ }^{20}$ Inteligensi erat hubungannya dengan proses berpikir. Berpikir adalah jiwa yang dapat meletakkan hubungan-hubungan antara pengetahuan. Berpikir merupakan proses "dialektis" artinya selama kita berpikir, pikiran kita dalam keadaan tanya jawab, untuk dapat meletakkan hubungan dengan pengetahuan kita. Dalam berpikir kita memerlukan alat yaitu akal (ratio). Hasil berpikir itu dapat diwujudkan dengan bahasa. Apabila digabungkan dengan inteligensi, maka dapat dijelaskan bahwa antara pikiran dan inteligensi memiliki hubungan yang erat yang saling isi mengisi. Adapun hubungan-hubungan yang terjadi dalam proses berpikir adalah: (a) Hubungan sebabmusabab, (b) hubungan tempat, (c) hubungan waktu, (d) hubungan perbandingan.

\footnotetext{
${ }^{20}$ Agus Sujanto, Psikologi Pengajaran, Cetakan Kelima, (Jakarta: Rineka Cipta, 1997), hlm.32
} 


\section{Metodologi}

Penelitian ini adalah metode survey dengan teknik korelasional, sesuai dengan pendapat Donald Ary dkk, ${ }^{21}$ mereka mengatakan bahwa survey dapat digunakan untuk menyelidiki hubungan atau untuk menguji hipotesa. Teknik korelasi digunakan untuk mengukur kadar hubungan antara pergaulan (X1) dan perkembangan moral (X2) dengan aktivitas belajar siswa (Y) baik yang sendiri-sendiri maupun bersama-sama. Penelitian ini berkenaan dengan hubungan antara berbagai variable, menguji hipotesis dan mengembangkan generalisasi, prinsip atau teori-teori yang memiliki validitas universal.

Variable-variabel dalam penelitian ini terdiri dari Pergaulan (X1), Perkembangan Moral (X2), dan variable Aktivitas Belajar Siswa (Y). berdasarkan kajian teori yang dibahas pada bab II, maka secara konseptual dan operasional variable-variabel penelitian dapat dijelaskan sebagai berikut:

\section{Variabel aktivitas Belajar Siswa}

a. Defenisi Konseptual

Aktivitas belajar siswa adalah kegiatan belajar siswa, baik yang terjadi di kelas maupun di rumah. Aktivitas belajar siswa di dalam kelas dikendalikan oleh guru, sedangkan di rumah dikendalikan dan dikontrol oleh orang tua siswa.

b. Defenisi Operasional Variabel

Aktivitas belajar siswa adalah skor yang diperoleh responden setelah menjawab instrument aktivitas belajar siswa yang berisi tentang tingkat keseriusan belajar siswa. Aktivitas belajar siswa diukur dengan indicator, 1) aktifitas dikelas, 2) aktivitas diluar kelas, 3) aktivitas dirumah, 4) aktivitas diluar rumah, dan 5) aktivitas di klub belajar.

c. Validitasi Instrumen

Validitasi aktivitas belajar siswa dihitung dengan menggunakan rumus Product Moment $^{22}$, Azwar juga mengatakan bahwa jika skor butir bukan dikotomi, tetapi bersekala interval, maka teknik korelasi product moment dapat dihunakan ${ }^{23}$. Hasil perhitungan validitas dibandingkan dengan table harga kritik $r^{\text {product moment }}$ Pada instrument direncanakan disebar sebanyak 25 soal. Selanjutnya untuk melihat realibitas aktivitas belajar siswa dicari dengan menggunakan rumus alpha cronbach $^{24}$.

\section{Variabel Pergaulan}

a. Defenisi Konseptual

Pergaulan adalah hubungan pertemanan yang dibangun oleh siswa dalam rangka menemukan jati diri dan juga sebagai sarana menambah pengalaman belajar dan bersosialisasi dengan teman-teman baik di sekolah maupun di luar sekolah.

b. Defenisi Operasional

Pergaulan adalah skor yang diperoleh responden menjawab instrument pergaulan siswa yang berisi tentang tingkat intensitas pergaulannya. Pergaulan siswa diukur dengan indicator, 1) cara memilih teman, 2) sarana interaksi, 3) sarana belajar, 4) suasana berteman, dan 5) bebas bergaul.

c. Validitas Instrumen

Validitas pergaulan siswa dihitung dengan menggunakan rumus Product Moment. Disamping itu, karena skor butir tidak bersifat dikotomis, tetapi berskala interval,

\footnotetext{
${ }^{21}$ Donald Ary, Lucy R. Jacobs dan Asghar Bazavieh, Introduction to Research in education, Cetakan Pertama, (New York: Holt, reinhart and Winston, 1970), h. 301.

${ }^{22}$ Norman E. Gronlund, Meusurement and Evaluation in teaching, Cetakan Kedua, (New York: MacMillan Publishing Company, 1985), h. 505

${ }^{23}$ Saifuddin Azhar, Realibitas dan Validitas, (Yogyakarta: Pustaka Pelajar, 1995), h.19.

${ }^{24}$ Anthony J. Nitko, Educational Test and measurement an Introduction, Cetakan Ketiga, (new York: Harcourt Brave Javanovich, inc., 1983), h. 396.
} 
maka teknik korelasi product moment dapat digunakan. Hasil perhitungan validitas dibandingkan dengan tabel harga kritik $r^{\text {product moment }}$ pada instrument disebar sebanyak 25 soal. Selanjutnya untuk memilih realibitas aktivitas belajar siswa dicari dengan menggunakan rumus alpha cronbach.

\section{Variabel Perkembangan Moral}

a. Definisi Konseptual

Perkembangan moral adalah perkembangan sikap siswa yang berkenaan dengan tingkat apresiasinya terhadap diri dan orang lain serta sikapnya terhadap pergaulan aktivitasnya, baik di sekolah maupun dilingkungan tempat tinggalnya.

b. Definisi Operasional

Perkembangan moral adalah skor yang diperoleh responden setelah menjawab instrument perkembangan moral yang berisi tentang tingkat apresiasinya terhadap diri dan orang lain dan juga perkembangan sikapnya. Perkembangan moral siswa diukur dengan indicator, 1) menanamkan sikap yang baik, 2) menentukan perilaku, 3) lingkungan moral, 4) potensi diri, dan 5) ukuran moral yangbaik dalam masyarakat.

c. Validitas instrument

Validitas perkembangan moral siswa dihitung dengan menggunakan rumus product moment. Disamping itu, karena skor butir tidak bersifat dikotomis, tetapi bersekala interval, maka teknik korelasi product moment dapat digunakan. Hasil perhitungan validitas dibandingkan dengan table harga kritik $r^{\text {product moment }}$ pada instrument direncanakan disebarka sebanyak 25 soal. Selanjutnya untuk melihat realibitas aktivitas belajar siswa dicari dengan menggunakan rumus alpha cronbach.

Dalam analisis data bagian akhir dilakukan perhitungan korelasi parsial dengan mengkorelasikan setiap variable bebas dengan variable terikat. Uji ini dimaksudkan untuk meyakinkan pada pengujian korelasi sederhana sebelumnya dan sebagai pengecekan kembali dengan metode korelasi parsial. Korelasi parsial ini dimaksudkan untuk menganganggap hubungan dengan variable dianggap tidak tetap. Apabila Y dikorelasikan dengan X1 (ry ${ }^{1.2}$ ), maka X2 dikontrol apabila y dikorelasikan X2 (ry $\left.{ }^{2.1}\right)$, maka X1 dikontrol. Sedangkan keberartian korelasinya dilihat dengan membandingkan $t^{\text {hitung }}>\mathrm{t}^{\text {tabel }}$.

\section{Pembahasan}

Pergaulan merupakan salah satu sarana bagi siswa untuk mewujudkan eksistensi dirinya dengan orang lain. Setiap siswa membutuhkan orang lain untuk membantu dirinya mengenal dan mempelajari lingkungannya. Oleh karena itu, pergaulan bisa dijadikan ajang bagi siswa untuk melatih dirinya memahami orang lain dan juga bisa dijadikan sebagai alat untuk membentuk pola kepribadiannya.

Aktivitas belajar tidak terjadi dengan sendirinya, tetapi karena ada pengaruh atau rangsangan dari luar dirinya yang memberikan dorongan untuk mengetahuinya. Disamping itu, dorongan keingintahuan yang kuat dalam diri siswa juga bisa menjadi pemicu atau faktor pendorong bagi siswa untuk melakukan aktivitas belajar. Pergaulan sehari-hari diyakini memiliki hubungan yang erat dengan keinginan siswa untuk melakukan aktivitas belajar. Oleh karena itu, semakin baik pola pergaulan yang dibangunnya, maka akan semakin baik aktivitas belajar dalam diri siswa. Pergaulan yang baik akan membawa dampak yang baik bagi aktivitas belajar siswa.

Perkembangan moral siswa senantiasa terjadi selama ia memiliki pergaulan yang cukup baik. Perkembangan moral sangat erat kaitannya dengan intensitas aktivitas siswa baik di sekolah maupun dilingkungan tempat tinggalnya. Karena moral merupakan bagian dari cerminan masyarakat yang dijadikan sebagai pegangan untuk melakukan aktivitas, juga 
dijadikan pegangan dalam menentukan baik dan buruk suatu perilaku atau perbuatan. Ukuran baik dan buruk dalam masyarakat selalu diukur dengan moral, baik moral yang berasal dari ajaran agama (akhlak) maupun moral yang berasal dari nilai-nilai yang berkembang di masyarakat.

Aktivitas belajar siswa baik di sekolah maupun di lingkungan masyarakat tidak terlepas dari pengaruh moral yang berkembang pada lingkungan masing-masing tersebut. Oleh karena itu, perkembangan moral diyakini memiliki hubungan yang sangat erat dengan aktivitas belajar siswa. Semakin baik perkembangan moralnya maka semakin baik pula aktivitas belajar yang dilakukan siswa.

Berdasarkan keterangan terdahulu, bahwa pergaulan yang baik memiliki dampak atau pengaruh yang baik terhadap aktivitas belajar siswa. Begitu juga dengan perkembangan moral memiliki hubungan yang cukup erat dengan perkembangan aktivitas belajar siswa baik di sekolah maupun di lingkungan tempat tinggalnya. Setiap variabel diyakini memiliki hubungan yang sangat erat variabel berikutnya. Artinya pergaulan dan perkembangan moral diyakini memiliki hubungan yang sangat erat dengan aktivitas belajar siswa. Se kin baik pergaulan dan perkembangan moral siswa, maka akan semakin baik pula aktivita ijarnya. Oleh karena itu pergaulan dan perkembangangan moral secara bersama-sam hubungan yang sangat erat dengan aktivitas belajar siswa.

\section{Kesimpulan}

Setiap pendidikan harus menyadari bahwa setiap fase perkembangan akan membawa perubahan baru pada anak, baik secara jasmani maupun rohani. Ada beberapa hal yang perlu diketahui orang tua sesuai dengan perkembangan anak, yaitu:

1. Setiap fase yang dialami oleh anak adalah masa peralihan atau masa persiapan bagi masa selanjutnya.

2. Perkembangan yang dialami oleh anak adalah perkembangan jasmani dan rohani. Oleh karena itu, dalam usaha membantu perkembangan anak, orang tua dan guru diharapkan agar memperhatikan perkembangan ini dan senantiasa melakukan kontrol dan pertimbangan agar tidak terjadi kelalaian pada diri anak.

3. Dalam keluargalah anak itu berkembang, oleh karena itu keluarga menduduki tempat penting bagi terbentuknya pribadi anak secara keseluruhan yang akan dibawa sepanjang hidupnya. Keluargalah pembentuk watak, pemberi rasa dasar keagamaan, penanam sifat, kebiasaan, hobi, cita-cita dan sebagainya, serta lembaga-lembaga lain di masyarakat adalah sekedar membantu, melanjutkan, memperbanyak dan memperdalam apa yang diperoleh dari keluarga.

Keluarga merupakan lingkungan yang pertama memberikan pendidikan yang berpengaruh terhadap perkembangan anak didik. Dalam keluarga anak akan mendapat kesempatan yang baik untuk memperoleh nilai-nilai moral keagamaan yang diterimanya dari orang tua. Fungsi kepemimpinan dan keteladanan orang tua dapat membentuk kepribadian anak, sedangkan pergaulannya di masyarakat secara fungsional dapat berdampak positif dan negatif terhadap perkembangan moral anak.

\section{Daftar pustaka}

Ary, Donald, Lucy R. Jacobs dan Asghar Bazavieh, Introduction to Research in Education, New York:Holt, Reinhart and Winston, 1970

Azhar, Saifuddin, Realibilitas dan Validitas, yogyakarta:Pustaka Pelajar, 1995.

Antony J. Nitko, Educational Test and Measurement an Introduction, New York:Harcourt Brave Javanovich, Inc., 1983.

Ahmad D. Marimba, Pengantar Filsafat Pendidikan Islam, Bandung:al-Ma'arif, 1986. 
Cronlund, Norman E., Meusurument and Evaluation in teaching, New York: MacMillan Publishing Company, 1985.

M. Athiyah al-Abrasyn, Dasar-Dasar Pendidikan Islam, Jakarta: Bumi Aksara, 1970.

Fasli Jalal, Stimulasi Otak untuk Mengoptimalisasi Kecerdasan Anak, Buletin PAUD, Jurnal Ilmiah Anak Usia Dini, Edisi 02, Jakarta:Direktorat PAUD, 2002.

Gerungan, W.A, Psikologi Sosial, Bandung:Erasco, 1991.

Hurlock, Elizabeth, Psikologi Perkembangan:Suatu Pendidikan Sepanjang Rentang Kehidupan, terj. Istiwidayanti, Jakarta:Erlambang, 1991.

Humadi, Tatap Angarsa, Akhlak yang Mulia, Surabaya:Bina Ilmu, 1991.

James Draver, The Pinguin Dictionary of Psychology, Aucland New Zeland: Penguin Book, 1981.

Mu'ti, Abdul, Proses Belajar: Pendekatan Kognitif, dalam PBM-PAI di Sekolah:Eksistensi dan Proses Belajar Mengajar Pendidikan Agama Islam, Semarang:Fakultas Tarbiyah IAIN Wali Songo Semarang, 1998.

Maslow, Abraham. H, Motivation and Personality, New York:Harper and Row Publishing, 1970.

Rayamulis, Ilmu Pendidikan Islam, Jakarta:Kalam Mulia, 2004.

Suyanto, Agus, Psikologi Perkembangan, Jakarta:Aksara Baru, 1999.

Slameto, Belajar dan Faktor-Faktor yang Mempengaruhinya, Jakarta:PT. Rineka Cipta, 1991.

Suwarno, Pengantar Ilmu Pendidikan, Jakarta:Aksara Baru, 1982.

Supraktiknya, A., dalam kata Pengantar, Hall, Calvin, and Gardner Lindsey, Teori-Teori Psikodinamik (klinis), terj. Yustinus, judul asli, Theories of Personality, Yogyakarta:Kanisius, 1993.

Supriono, Widodo, Filsafat Manusia dalam Islam, Reformasi Filsafat Pendidikan Islam, Pustaka Pelajar, Jogyakarta, 1996.

Ulrich Neisser, Cognition nd Reality, San Fransisco: W.H. Freeman, 1976, hlm.1.

Winkel, WS., Psikologi Pengajaran, Jakarta:Gramedia Widya Sarana Indonesia, 1989. 